\title{
Social Impacts of Protected Areas on Gender in West Kilimanjaro, Tanzania
}

\author{
Sayuni B. Mariki \\ Department of Wildlife Management, Sokoine University of Agriculture, Morogoro, Tanzania \\ Email:zion2000tz@yahoo.com,zion@suanet.ac.tz
}

Received 26 February 2016; accepted 26 March 2016; published 29 March 2016

Copyright (C) 2016 by author and Scientific Research Publishing Inc.

This work is licensed under the Creative Commons Attribution International License (CC BY). http://creativecommons.org/licenses/by/4.0/

(c) (i) Open Access

\section{Abstract}

In most cases, the establishment of protected areas (PAs) goes hand-in-hand with an increase in conservation costs to communities living adjacent to these PAs. This paper draws insights from gender theories in particular feminist political ecology approach to unravel the impact of PAs on men and women around the Kilimanjaro National Park (NP) and the Enduimet Wildlife Management Area (WMA) in Tanzania. Specifically, it investigates how the creation and expansion of two PAs in Tanzania have impacted men and women in different ways. A combination of in-depth interviews, focus-group discussions, and key informant interviews was used to collect data from local people who live adjacent to these PAs. The findings reveal that the PAs impact both men and women, but the most significant impact is felt by women due to inequality in the gendered division of labour and resources at the household level. Poor men and women together with most women in female-headed households, suffer more from strong restrictions on access to PA-based resources than other people as they have limited alternatives. The benefits of PAs in compensating for resource restrictions were found to be modest and do not meet the needs of predominantly poor men and women. The majority of local people collect resources from PAs illegally to meet their livelihood needs, despite restrictions on resource access. This study concludes that, instead of PAs paying attention to people's relevant livelihood needs and improving their wellbeing, they have unfortunately worsened their situation.

\section{Keywords}

Conservation, Resource Access, Gendered Impacts, Livelihoods, Protected Areas

\section{Introduction}

Most of the world's poor populations (an estimated 1.6 billion people) rely heavily on non-cultivated natural re- 
sources for their income and household use [1]. In Africa, approximately two-thirds of 600 million people depend on natural resources for cash and/or subsistence income [2]. Given such widespread reliance on natural resources, there is much pressure to conserve more areas, including land used by small-scale farmers and pastoralists [3]. This pressure is linked to growing recognition of the importance of protected areas (PAs) in conserving biodiversity richness, promoting ecosystem services and mitigating against climate change, as well as increasing rate of global deforestation, preventing species extinction, and conserving land and water resources [4].

In modern times, the number of PAs had grown from less than 1000 in 1940 [5] to over 161,000 in 2010, representing over $13 \%$ of the world's land surface area [6]. Almost all the strictest categories of PAs (categories I and II) under the International Union for the Conservation of Nature (IUCN) are found in the developing world [7]. Governments, conservation organisations, and private entities have established PAs aimed at promoting national development and public interest, adopting conventional exclusionary approaches, however, there is mini$\mathrm{mal} /$ no consideration of the implications for the people who depend on these areas for their livelihoods [8].

The majority of Tanzanians (75\%) live in rural areas where they rely heavily on natural resources for their livelihoods [9]. For instance, over $90 \%$ of inhabitants rely on wood and other vegetation to provide domestic energy [10] [11]. Nevertheless, about $40 \%$ of Tanzania's land area is under conservation measures [12], coupled with restrictions. Although many PAs generate economic benefits and services, much of these benefits are enjoyed by national and international elites [13] [14], while most of the conservation costs are borne almost entirely by the local people, particularly poor and politically weak groups [15]-[17].

Previous studies have found that local people are disempowered when the control of natural resources is taken over by government or private investors [18]. In most cases, local communities are left without alternatives, which in the long run, results in squatting, encroachment and poaching to keep them alive [19]. Furthermore, restricting access to resources such as firewood is reported to be problematic [20] [21], as wood provides about 70\% of the energy consumed in Africa [20].

While many studies have focused on the livelihood impacts of PAs on local communities (e.g. [17] [22]) some studies have failed to understand communities as heterogeneous entities composed of multiple actors with different and dynamic interests [23]. Such heterogeneities imply that different actors may be impacted differently by conservation measures. Gender is a particularly important category to examine because it cuts across all other categories. Dependence on natural resources tends to be gender specific due to existing gender divisions in terms of labour, rights, and responsibilities [24]. For example, women in rural areas in Tanzania collect firewood, fodder, and wild foods mainly for household use, while men rely on natural resources such as timber, animal protein, and poles, mainly for sale [25]. Research in rural Tanzania has found that women in some areas walk up to $10 \mathrm{~km}$ a day collecting and carrying firewood with loads of up to $38 \mathrm{~kg}$ [26]. Men face additional challenges such as guarding crops against raiding by wildlife [27], and the loss of income sources.

There are several studies in various parts of the world that have investigated the impacts of conservation practices on gender roles (e.g. [28]-[31]. In Tanzania, particular studies have focused on gender and natural resources. For instance, [32] investigated gender participation in natural resource management; [33] studied gender-specific utilisation and conservation of natural resources; [34] investigated gender equitable entitlements of coastal resources; and [35] discussed women's land rights in Tanzania. Very few studies however, have attempted to document the magnitudes of these impacts on men and women, particularly when they try to exercise their former resource user rights, i.e. before the establishment and expansion of PAs).

This study therefore investigates how the creation and expansion of two PAs in Tanzania have impacted men and women in different ways. In recent years, the Government of Tanzania has appropriated large tracts of land for conservation and vested the authority and control of these areas in the state and private sector. In West Kilimanjaro area, the Kilimanjaro National Park (NP) was expanded in 2005, and the Enduimet Wildlife Management Area (WMA) ${ }^{1}$ was established in 2007. According to the International Union for Conservation of Nature (IUCN) classification, Kilimanjaro NP is classified in category II (area managed mainly for ecosystem protection and recreation) and Enduimet WMA is classified in category VI (as a protected area with sustainable use of natural resources). These PAs are subject to restrictions on access to natural resources, hence involving considerable risks for women and men who try to access such resources. Besides access restrictions, there have also been increases in conservation costs to local communities. I argue that instead of PAs improving the livelihoods and wellbeing of men and women, they have threatened and exacerbated their situation. Men and women are regarded by PAs staff as being destructive and a threat to conservation practices, rather than as major stake-

\footnotetext{
${ }^{1}$ WMAs are portions of village land set aside for conservation, with the intention to of generating revenues from tourism [37].
} 
holders in the conservation process [36].

The reasons for selecting the two protected areas in this study are that they are located in the same ecosystem and they were created or expanded in recent years. The creation of these areas is associated with changes in natural resource control and access rights. Investigating the impacts of such PAs on local men and women can shed light on injustices in the form of restricted access rights, and provide evidence that may lead to their reduction if not their discontinuation. The following section provides a brief theoretical framework, followed by the research methodology adopted for this study. Thereafter, the findings and discussions are presented followed by conclusions.

\section{Theoretical Perspective}

Over the years, the development programs have been condemned for disregarding gender roles and its impact on men and women. Nonetheless from 1970s, many development planners and donor agencies became increasingly aware of the need for more participatory approaches to development and gender-specific nature of use of the environment. At that time there was a shift in development where "women in development" (WID) was adopted as an approach to include women in development. This approach was driven by the resurgence of women's movement in northern countries. It focused on unequal gender inequalities in division of labour, access to natural resources, wage rates, participation in decision making, health and education [38] [39]. However, WID did not tackle the unequal gender relations and roles at the basis of women's exclusion and gender subordination.

The women and development (WAD) approach emerged in the 1980s. It argued that women were main victims of environmental degradation thus were the most appropriate contributors to protect the environment [39]-[41]. Based on this, many development programs and conservationists became concerned about environmental sustainability hence recognized the need to work with local people particularly women due to the important role they play in resource management [42].

WED emerged with emphasis on a special relationship between women and the environment [39] [41]. The gendered division of labour formed one starting point for women, environment and development (WED). Naturally, women's responsibilities give them distinct interests in, and make them closely dependent on natural resources. Based on their daily environmental experiences, women have a deep and extensive knowledge of natural resources. Moreover, it is argued that women's interests lie in sustainable environmental management [43]. Gendered division of labour is a suitable means of defining unequal power relations between men and women in the communities and households. Normally, men control and dominate occupations directly related with the use of natural resources such as forests, land, animals, plants and the waters. Their work often eclipses women's contributions to natural resource management and work in these communities [44].

Nevertheless, much of this work is characterised by political ecology approach, particularly in its attempts to look beyond the idea of a women special connection with nature towards an examination of wider inequalities in gender divisions of labour, property and power. The idea of women connection to the environment have faced criticism among many academics working in the development field because WED treat women as a homogenous group making no distinction between class, age, ethnicity, marital status or region [45] [46]. In order to encourage deeper investigation of gender-environment relationships, advocates of feminist environmentalism (e.g. [40]) and gender analysis (e.g. [47]) perspectives have been calling moving from WED to gender and development (GAD), and gender, environment and development (GED) perspectives.

Feminist political ecology (FPE) emerged in the 1990s as a subfield of political ecology, building on previous work by feminist scholars, and feminist theorists [24] [48] [49]. The approach has extended "the multiple scale analysis of environment and power in political ecology to gendered relations both within and beyond the household, from individual to national scales” ([50], p. 722). FPE critically investigates concepts such as community, household, homogenous conditions, and shared interests [50]. Gender is considered to be a critical factor in "shaping resource access, and control, interacting with class, caste, race, culture and ethnicity to shape processes of ecological change, the struggle of men and women to sustain ecologically viable livelihoods, and the prospects of any community for sustainable development” ([24], pp. 4-5). In particular, access to and the control of natural resources are structured by power relations and authority that are embedded in formal (e.g. the state, and global rules and regulations) and informal (e.g. social norms) institutions at local, national and international levels [51]. Access to natural resource can be viewed spatially, across the landscape, or by scale, in relation to hierarchically arranged political economic structures that influence local use [52]. In order to understand differential 
control over resources, power hierarchies, and relationships between men and women, feminist researchers have argued for a thorough examination of intra-household gender dynamics because the household is a complex arena and a very important institution, in which power and resources are bargained and distributed [28].

As can be expected, the main emphasis in FPE is skewed largely towards a focus on women. For example, according to [24] the term "gender" seems to be used synonymously with "women". [49] warns against the danger in such a "conceptualization of falling back into essentialist understandings of women and their natural connection to the land" (p. 169).

The term "gender" does not only imply "sex, a set of the genetic, hereditary, and biological characteristics that structure men and women" ([53], p. 11), but rather, the socially constructed relations and differences between men and women that define roles, identities, entitlements, and perceptions. These relations frame the ownership of assets and access to resources, and affect structure and decision making within families, communities, and institutions [53] [54]. The situation varies depending on geographical area, context, situation, and time period, and can be negotiated based on an individual's position within hierarchies such as age, class, seniority, or ethnicity, own life cycle and agency [54].

In the field of biodiversity conservation, considering a gender perspective entails understanding and incorporating the differences and relations between men and women into conservation initiatives [53]. This includes consideration of the different roles, opportunities and rights of men and women in terms of access, use, conservation and management of natural resources [53]. It also involves understanding the various ways in which conservation problems affect both men and women [53].

The terms "women" and "men" do not refer to a single homogenous group, but rather to actual material differences among men and women in relation to nature and the environment [55]. For instance, the position of women or men in a nomadic tribe might be completely different to those in a sedentary tribe. It is crucial to examine factors such as class, ethnicity, age, and sociocultural affiliation when studying differences between men and women in relation to the impacts of conservation.

The findings will provide deeper insight into the conditions shaping gender-environment relationships, and will illuminate the nature of gender inequities associated with wildlife conservation in Kilimanjaro NP and Enduimet WMA.

\section{Study Area}

This study was conducted in three villages bordering the Kilimanjaro NP (in the Siha Magharibi Division) Engare Nairobi, Matadi and Namwai, and three villages bordering the Enduimet WMA (in the Enduimet Division) - Tingatinga, Olmolog and Sinya. These villages are located in the West Kilimanjaro basin in the Siha and Longido districts of the Kilimanjaro and Arusha regions respectively. The altitude of the area is 1230 to $1600 \mathrm{~m}$ above sea level. The area experiences bi-modal rainfall. The long rains last from March to May while short rains fall from November to December. In 2009, the population of the Siha and Longido districts was 121,000 and 96,244 respectively while that of the three study villages of the Kilimanjaro NP was 23,411 and that of the Enduimet WMA was 12,922.

\subsection{Kilimanjaro National Park}

The Kilimanjaro NP was established in 1973 with an area of $753.81 \mathrm{~km}^{2}$. The park is surrounded by the Kilimanjaro Catchment Forest Reserve that was established in 1940 covering an area of $1078 \mathrm{~km}^{2}$, with a boundary length of $238 \mathrm{~km}$, encompassing three districts (Hai, Moshi Rural, and Rombo) in the Kilimanjaro region. There is a Half Mile Forest Strip (HMFS) with an area of $87.69 \mathrm{~km}^{2}$ and a width of $0.8 \mathrm{~km}$, around most of the forest reserve that was approved in 1941 by the British colonial government as a buffer zone between the forest reserve and the villages on the lower slopes of the mountain. This buffer zone provides local people with wood and non-wood forest products [56 $]^{2}$. Between the forest reserve and the villages in north-west Kilimanjaro, there are patches of forest plantations $\left(60.19 \mathrm{~km}^{2}\right)$ established in 1954 by the British colonial government and expanded after independence in 1961 for the production of timber and poles [57]. The forest reserve borders 90 villages, with 70 villages being adjacent to the HMFS.

Before 1998, forests in Tanzania were managed centrally by the Forest and Beekeeping Division (FBD) under

\footnotetext{
${ }^{2}$ The north western side of the forest reserve, including the study villages, does not have a HMFS.
} 
the Ministry of Natural Resources and Tourism. Their management was ineffective, thus leading to continued deforestation. In response to the situation, a new forest policy was released in 1998. It promotes among other things, the involvement of local people in the management of and benefits arising from forest products [11]. Based on this experience of involving local people, Joint Forest Management (JFM) was introduced to the Kilimanjaro Catchment Forest Reserve, to allow access to forest resources.

In 2001, the United Nations Development Program/Global Environmental Facility Small Grants Program conducted an aerial survey that revealed major threats to Mt. Kilimanjaro ([58], p. 5). The survey report initiated a process to include the forest reserve in the Kilimanjaro NP [59] [60]. Thus, in 2005, the forest reserve (formerly managed by the FBD) was officially gazetted as part of the Kilimanjaro NP [61].

The three selected villages in the Kilimanjaro NP are located close to one of the routes leading to Mt. Kilimanjaro, called Londros. They are occupied by the Chagga, Safa and, Pare tribes, and other small ethnic groups. Most villagers are small-scale farmers, small-scale livestock keepers, small-scale business people, casual labourers, and tourists' porters. Some people practice the taungya ${ }^{3}$ system in the forest plantation, and some are labourers in the forest plantation and/or large-scale farmers.

The villages border the Endarakwai Ranch, the National Ranching Company, the Kilimanjaro NP, the West Kilimanjaro Forest Plantation, and agricultural plantations. In the private Endarakwai Ranch and the Kilimanjaro NP, people are prohibited from harvesting natural resources such as fodder, firewood, and plants for traditional medicine.

The division of labour in these villages is strongly gender based. Women are responsible for all domestic tasks such as caring for children, collecting fodder and firewood, fetching water, preparing meals, and farming. Young girls assist their mothers with household chores and farm tasks. Men concentrate mainly on income related activities such as casual labour, employment, farming, the timber/logs business, and assisting tourists as porters. Due to unequal power relations between men and women, women are forced to do activities that do not involve cash benefits such as community work, and household chores.

Moreover, women's participation in decision-making and village leadership is limited to village government membership and not top leadership. The village chairpersons and executive officers in the villages studied are all men. In the village government there are 10 female members out of 25 in Engare Nairobi, 7 out of 25 in Namwai and 12 out of 25 in Matadi. However, some women stated that although they are village government members, their views are often not taken seriously and the sole decision makers are men. Most household heads are men ${ }^{4}$ and very few women are public employees.

\subsection{Enduimet Wildlife Management Area}

The Enduimet WMA is a community-based conservation area that covers $742,275 \mathrm{~km}^{2}$. It was established following a wildlife survey report in 1997 that revealed a decline in the wildlife population due to bush meat "poaching" [63]. A Community-based Organisation (CBO) was established in 2004 to manage the area with 27 members ( 9 women and 18 men). The Enduimet WMA is divided into three management zones by the Monduli District Authority in order to regulate land use. These zones are the Olkunonoi-Kitendeni Zone (a wildlife corridor), the Ronjoo Zone (an area for economic and tourism activities covering $80 \%$ of the WMA), and the Embarnati Zone (settlement area) [64].

The Enduimet WMA acts as the migratory route to various PAs such as the Kilimanjaro, Arusha, and Amboseli national parks. Due to the movement of wildlife in the region cases of wildlife damage are common, such as crop raiding, killing of livestock and threats to human life in villages located in close proximity to these PAs.

The three selected villages in the Enduimet WMA are occupied mainly by the IlkisongoMaasai who are pastoralists and agro-pastoralists. The Maasai are "well known for their strong socio-cultural practices and norms that govern all dimensions of their community" ([65], p. 3). They are very patriarchal with women generally being regarded as inferior, without "property ownership rights, access to social services, and the power to make decisions on their own lives” ([65], p. 2). Men own the livestock and can make decisions about selling them and, spending the money without the involvement or consent of their wives (Interview No. 19, Sept. 2009).

The division of labour in these villages is also gender based. Men are responsible mainly for livestock grazing

\footnotetext{
${ }^{3}$ Taungya is an agroforestry system in which short-term food crops are grown in a forest in the early years of tree growth [62].

${ }^{4}$ In this study a "household head" refers to a person who controls the maintenance of the household and exercises the authority to run the household.
} 
and protection. Women are responsible for all domestic tasks, including building bomas (huts), milking cows, collecting water and firewood for domestic use, cooking, looking after children, growing crops in small fields for basic food supply, partly taking care of small livestock, and preparing young girls for marriage [66]. Some women also make bead jewellery which they sell to tourists, markets or wholesalers. Very few women engage in small-scale business, politics, or public employment.

Employment and leadership are considered to be activities mainly for men. The Maasai elders are highly respected, and are considered to be decision makers. In all the villages studied, the chairpersons and village executive officers are men. In the village of Sinya, for example, only six members out of 26 in the village government are women.

Men generally do not associate with women, but uncircumcised boys may mingle with women. Most men who own many cows practice polygamy because they are capable of paying a "bride price" of up to 40 cattle.

In most Maasai communities the female literacy rate is lower compared to their male counterparts. This is because many girls are forced into early marriages, have heavy workloads, and lack support for education (see also [67]). Many young women do not generally attend meetings. Due to strong cultural constraints, very few women, mostly the "modern" and non-Maasai women are confident enough to speak during group meetings in the presence of men (Figure 1).

\section{Methodology}

Fieldwork was conducted in different periods between 2009 and 2014. Interviewees were chosen purposively based on gender, living proximity to the PAs, and dependence on PAs. Data were collected on the gender-based division of labour, power relations, access to resources at the household level, livelihood activities, access to natural resources, costs of conservation, benefits received from the PAs, and livelihood alternatives. Interviews were conducted in Kiswahili, a language in which most people in the study area are fluent. The interviews involved 41 men and 50 women.

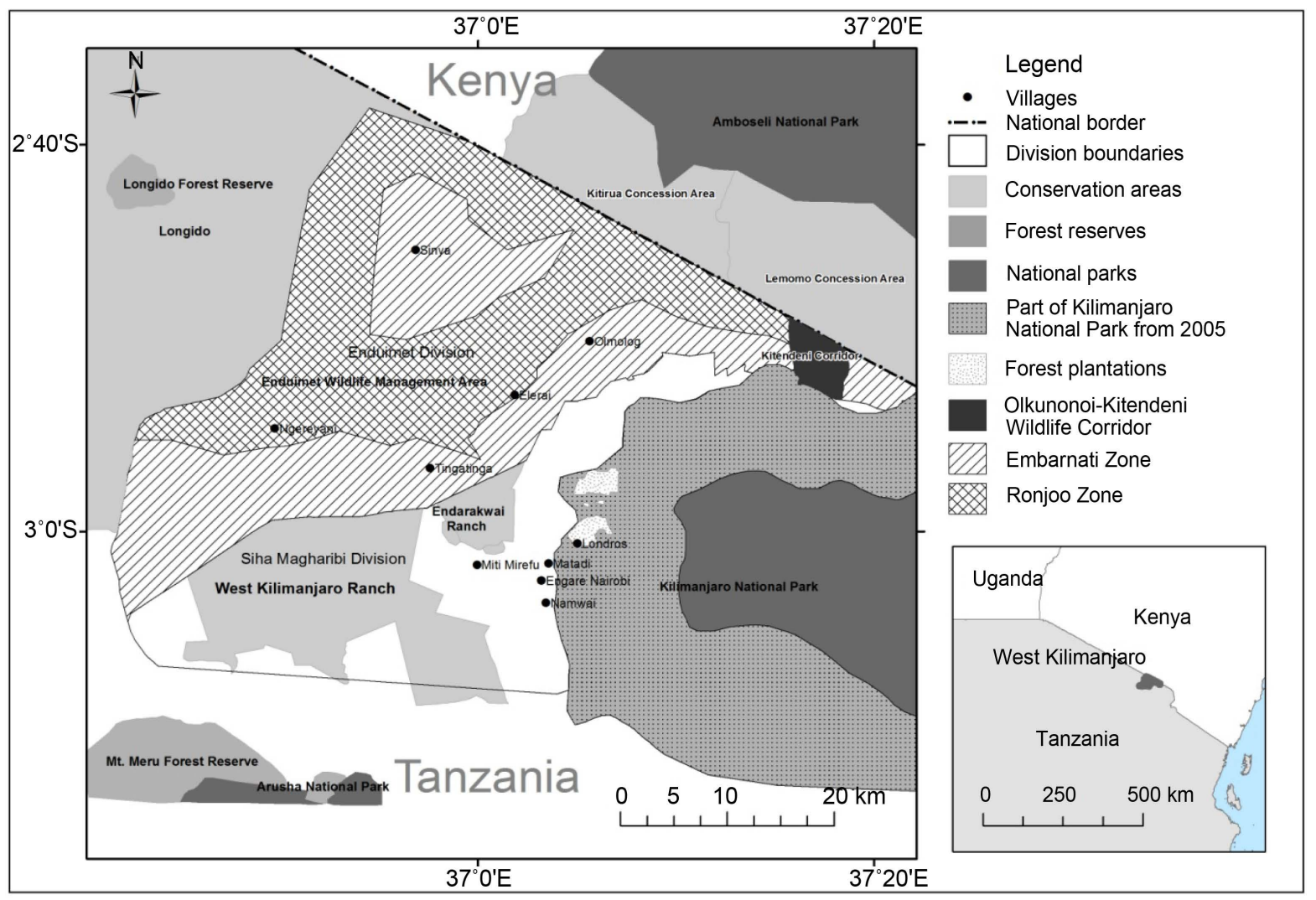

Figure 1. A map locating the study villages in West Kilimanjaro, Tanzania. 
The sample size was limited when further data no longer added new insights in answering the research questions. The interview sessions lasted between one and two hours. Participants were encouraged to express themselves freely, and they were guaranteed anonymity and confidentiality. Although I used a Maasai man as a research assistant to assist me when interviewing Maasai men, very few Maasai men felt free to discuss gender matters.

Six focus group discussions (three from each PA) were conducted, generally with 6 to 10 people in order to gather various viewpoints on how men and women are impacted by PAs. This method was mainly a triangulation tool used to determine the representativeness of the answers obtained during the interviews. At first, the focus groups included both men and women. However, in these groups, few women felt free to express their views in the presence of men. Thus, in order to provide an opportunity where both men and women could express themselves freely, I conducted groups that involved men alone, women alone, and both men and women. Separating men and women enabled me to understand for instance, how traditional power relations have prevented women from airing their concerns; how leadership dominated by men has curtailed women's development such as training and employment; and why women have limited power over household resources. Nevertheless, in groups where powerful women such as political leaders were present, some women were reluctant to express their concerns. In these cases, I followed up with key informants or/and other group discussions.

I attended a women's meeting in the village of Tingatinga where I learned and observed various issues surrounding women and their environment. A few women from wealthy families dominated the meeting. I also attended a village assembly in Engare Nairobi, where I gained insights on relationships between men and women, and conservation issues. At this meeting, some women contributed although most of the discussions were dominated by men. I further engaged in participant observation and informal interviews in order to learn about local people's everyday activities in relation to the PAs.

Finally, I reviewed relevant documents and several other studies that have been conducted in the area. I used a field notebook to record information, and where permission was granted, I used a tape recorder. After data collection, all recorded data were transcribed, later organised into categories, and grouped into themes. The identified core themes were linked to the aims of the study, and these served as the basis for my findings and discussion presented below. Statements supported by appropriate quotations from the interviews are provided where necessary to elucidate the particular theme.

\section{Results and Discussion}

\subsection{Impacts of the Expansion of Protected Areas on Gender}

The analysis of field data revealed five main themes: impacts on access to natural resources, impacts associated with illegal entry and/or withdrawal of natural resources, impacts on human-wildlife conflicts and living costs, impacts on relationship between communities and protected areas' staff, and livelihood alternatives. A description and discussion of each theme is presented in the following sections and the summary of the impacts is presented in Table 1.

\subsubsection{Impacts on Access to Natural Resources}

Following the inclusion of the forest reserve in the Kilimanjaro NP, the reserve became a "no use" "no entry" zone. Access to and the withdrawal of natural resources was prohibited, as one man explained:

When we were under Forestry and Beekeeping Department (FBD) we had a very good system. If a villager wanted firewood for cooking, we paid US\$3 for a tractor full of firewood. We were also allowed to cut grass, collect firewood, and some other forest products twice a week. All are now restricted. (Interview no. 1, Nov. 2009)

The change in user rights was made without the full involvement and awareness of all community members. It was a top-down exercise, with no space for representation of the ideas and interests of the communities. The park staff did conduct random household surveys, in which they talked to household heads who were mainly men (cf. [68]). Unclear user rights led some women to continue with their former routine of withdrawing resources from the forest as they had done under the previous FBD regime (Interview No. 4, Nov. 2009). Several studies have revealed that almost all decisions concerning the management of wildlife resources in Tanzania are made by the central government, without consultation with the affected local communities (e.g. [36] [63] [69]). 
Table 1. Overall gender impacts associated with the expansion of the Kilimanjaro NP and the creation of the Enduimet WMA.

\begin{tabular}{|c|c|c|}
\hline & Women & Men \\
\hline $\begin{array}{l}\text { Restricted access to } \\
\text { natural resources }\end{array}$ & $\begin{array}{l}\text { Firewood (increased time, labour, } \\
\text { health effects-miscarriage, chest, } \\
\text { back pains, falls); } \\
\text { Fodder (increased time, labour, } \\
\text { health effects-miscarriage, chest, } \\
\text { back pains, falls); } \\
\text { Loss of livelihoods (selling } \\
\text { firewood, fodder, charcoal); } \\
\text { Physical impacts (harassment, tools } \\
\text { confiscated, rape, beatings); } \\
\text { Psychological effects (fear, stress); } \\
\text { Increased cost of living (buying } \\
\text { fodder, firewood). }\end{array}$ & $\begin{array}{l}\text { Loss of source of income (selling } \\
\text { fodder, firewood, charcoal, honey, } \\
\text { wildlife meat); } \\
\text { Loss of source of protein (traditional } \\
\text { hunting); } \\
\text { Physical impacts (beatings, death, } \\
\text { imprisonment); } \\
\text { Psychological effects (fear, stress); } \\
\text { Increased cost of living (fines, buying fodder, firewood). }\end{array}$ \\
\hline $\begin{array}{l}\text { Human-wildlife } \\
\text { conflicts }\end{array}$ & $\begin{array}{l}\text { Crop raiding (food insecurity, } \\
\text { economic loss, increased } \\
\text { agricultural labour); } \\
\text { Livestock killings, injuries } \\
\text { Destruction of water infrastructure } \\
\text { (increased labour and time to } \\
\text { search for water); } \\
\text { Psychological impacts (fear); } \\
\text { Limited freedom of movement at } \\
\text { night; } \\
\text { Sleepless nights (guarding crops); } \\
\text { Fencing (increased time, labour, } \\
\text { resources); } \\
\text { Increased living costs (buying food, } \\
\text { buying materials for mitigation measures, paying for } \\
\text { guarding crops when time is not available). }\end{array}$ & $\begin{array}{l}\text { Crop raiding (economic loss, increased } \\
\text { agricultural labour); } \\
\text { Human injuries, death; } \\
\text { Livestock killings, injuries (income } \\
\text { loss); } \\
\text { Sleepless nights (guarding crops); } \\
\text { Psychological impacts (fear); } \\
\text { Limited freedom to stay outside at } \\
\text { night; } \\
\text { Destruction of water infrastructure; } \\
\text { Increased living costs (buying food, } \\
\text { buying materials for mitigation measures, paying for } \\
\text { guarding crops when time is not available). }\end{array}$ \\
\hline Relationship & Enmity & Enmity \\
\hline
\end{tabular}

Source: Fieldwork data.

The creation of the Enduimet WMA has restricted men and women in terms of the amount and type of subsistence natural resources they may collect, and the numbers of livestock that may graze in the area. For example, grazing high numbers of livestock (conducted mainly by men ${ }^{5}$ ) is restricted in the WMA. Charcoal burning, the collection of firewood for sale, farming, tree cutting, and sand or gravel extraction are all prohibited to both men and women. Only collection of dry twigs and branches (done mainly by women) for firewood is allowed for household purposes.

Although the land devoted to the WMA belongs to villagers, men and women do not have any power to negotiate on resource use in the WMA. This indicates that the government has stretched its powers and authority to control what are claimed by government to be "village resources". The women interviewed claimed to have become victims when restrictions were imposed because they lack alternative income sources (Interviews No. 38, 2009; 43, 2012).

Men and women are affected differently in terms of access to natural resources according to their economic situation. For instance, in Kilimanjaro NP, the well-off women are less affected by resource restrictions because they can afford to buy fodder, firewood or rejected timber from industries, which is not the case for the poor counterparts. The poor men and women expose themselves to more risks as they enter the forest illegally to collect fodder and firewood for sale or for household use (Interview No. 18, 2009). West Kilimanjaro has several sawmills (e.g. Tanscan Timber Co., Fadhila Sawmill, Vijana Sawmill) due to the presence of the West Kilimanjaro Forest Plantation. In the sawmills, timber splitting is done twice a year. The owners sell the rejected timber to local people for activities such as cooking as stated by one well-off woman: "I do not go to the forest because I don't want to fight with park rangers. I buy the rejected timber for cooking from that sawmill!” (Interview no. 17, Nov. 2009).

\footnotetext{
${ }^{5}$ The Maasai keep large numbers of livestock; thus they practice open grazing.
} 
Similar findings have been reported by [70] showing that women and the poorest people experienced the strongest negative conservation impacts while well-off emerged as relative winners among those affected.

However, because timber production in the plantation is low (Interview with plantation management, 2012), rejected timber is very expensive and affordable by few people. The villagers claim that the rejected timber is not readily available because business people purchase it and sell it in nearby towns. One full truck of rejected timber was sold for about US\$ 200 (Interview with plantation management, 2012).

Women in female-headed households are affected more by resource restrictions than women in male-headed households. This is because many female-headed households lack sufficient labour power, relatives willing to help, and some are old and sick and thus have less energy. As one old widow expressed it: "I cannot walk long distances, I might have food but lack firewood to cook it...” (Interview No. 43, 2012). Another woman stated that: I have a relative willing to help but the help is occasional... (Interview No. 44, 2012). Very few such women can afford to buy fodder and firewood, and thus many walk longer distances in search of these resources. Consequently, this situation increases their workload, and limits their time for household chores, participation in income generating activities, and educational or training opportunities (cf. [30] [71]).

Some families in the vicinity of the Kilimanjaro NP have their own plots that provide fuel wood and fodder. However, women are not allowed to harvest any tree without their husband's permission. They may only access those branches that are unfit for sale, after the harvest.

\subsubsection{Impacts Associated with Illegal Entry and/or Withdrawal of Natural Resources}

Firewood is the main source of energy in the villages studied (cf. [72]). [62] found that about 92\% of households in three districts (Moshi Rural, Hai and Rombo) adjacent to the Kilimanjaro NP depend on firewood as their main source of energy. The buffer zone (half-mile forest strip) provides $64 \%$ of firewood; while own plots, the buffer zone, and the forest reserve provide about $61 \%$ of fodder [62]. These findings show that people from the three districts enter the forest reserve to supplement their collection of forest products, despite having the buffer zone. The consequence of a lack of a buffer zone in West Kilimanjaro is high and exposes men and women to more risks when compared to local people in other parts bordering the Kilimanjaro NP. Possible explanations for the lack of a buffer zone in West Kilimanjaro might be the presence of agricultural plantations bordering the natural forest dating from the 1950s. The villages that border the plantations were established in the 2000s. During inclusion of the forest reserve into the Kilimanjaro NP, the park promised to demarcate a buffer zone for local people, but the promise seems improbable.

The findings of this study show that, if they access forest products from the Kilimanjaro NP, men and women run the risk of severe punishment from park rangers. Women's gender roles bring them into contact with the PAs often and thus they are at a high risk of violent action from park rangers. Women in the Namwai village for instance, informed me that there is no dead wood in their village; they sometimes have to walk deep into the forest and are afraid of being raped or tortured by the park rangers (Interview No. 12, Nov. 2009). Some women claimed to be harassed, beaten, raped, had their tools confiscated by park rangers, and some suffered a miscarriage as one stated: "The problems we are facing are rape and beatings when we go to the forest to collect firewood and fodder. Three women went to the forest and they were raped...” (Interview No. 2, Nov. 2009).

These claims are not reported to the village government because victims know that entering the Kilimanjaro NP is illegal. The village chairperson asserted that: "I heard those claims but no one so far has reported to me because they are afraid. Nothing we can do, there is so much harm...” (Interview No. 3, Nov. 2009). However, the Kilimanjaro NP Protection Warden denied such claims: “...there is no such a thing, it has never happened!” (Interview no.6, Dec. 2009).

It is not only women who suffer, but men are also sometimes severely beaten by park rangers. No man without a permit found in the forest by park rangers would leave unbeaten (Interview No. 15, Nov. 2009). Even if a victim has surrenders it was reported that park rangers keep on beating him as one man stated:

About a month ago (in 2009) a man was caught in Kilimanjaro NP trapping an animal... They beat him until he became unconscious. They used knives to cut his feet. It was a very brutish action... When they beat you it is not a joke! (Interview No. 9, Nov. 2009).

After such beatings, the victim is taken to court; and depending on the magnitude of the offence, he can be imprisoned or fined.

Consequently, men have developed a fear of going into the forest because they are not sure whether they will 
come back alive or not, as one man expressed:

Men were afraid of grazing livestock in the forest during the drought period because some people were found dead. There was not enough evidence of who killed them. This year (2009) one young man was killed and the body stayed two weeks in the forest. We went and collected the bones. The park rangers took the bones, and they have never returned them. They said they were going to check them in the laboratory. Then another one was killed, but there was no direct evidence. It is terrifying! (Interview No. 13, Dec. 2009)

The above findings indicate that park rangers are involved in unethical and improper implementation of protection activities, and they even violate human rights. Similar excessive use of force against local people has been reported by [73] who recorded that park rangers shot and killed a person in the Kilimanjaro NP. Elsewhere in Tanzania, several allegations of harassment of local people in the process of the expansion and establishment of PAs have been made (e.g. [15] [69] [74] [75]). Similar findings were reported in India, in Uttarakhand [28] and Gujarat [31], and in Nepal [29].

Men are often killed because they fight back in the event of torture. Instead of reasonable force, park rangers respond with excessive force. In addition, there is evidence of the practice of the inherited protectionism philosophy of "shoot and kill”, where traditional hunters pay with their lives. [5] exposed a case in the Serengeti NP in Tanzania where park rangers found 19 traditional Kurya hunters in the park; ten escaped, one was wounded, and eight were executed (See also [69]).

In the Enduimet WMA, notably in the villages of Tingatinga and Ngereyani, both men and women go into the bush to burn charcoal. When game scouts find them, their kilns are destroyed, their tools are confiscated, and they are later punished by the village government according to bylaws (Interview No. 23, Sept. 2009). Several studies in Africa (e.g. [76]) reveal that it is mostly men who conduct charcoal burning. This study found that both men and women participate in the practice, with men's kilns being bigger (50 - 60 charcoal sacks) than those of women. Men who participate in charcoal burning are mostly outsiders with only a few being from the villages. Women burn charcoal as an economic alternative to supporting their families mainly after severe droughts and/or crop raiding by wildlife (Interview No. 23, Sept. 2009). Charcoal is sold mainly to neighbouring centres such as Namanga, Oldoinyosambu, Sanyajuu and Bomang’ombe. Charcoal burning is claimed to be labour intensive and time consuming yet it offers very low returns. This is because it holds risks, and sometimes men and women are injured in the process of fleeing from game scouts. Charcoal burners in the area are considered to be a nuisance and enemies of the environment. In the interviews I conducted, women avowed to know the effects of burning charcoal on the environment, but several of them said that they have to continue because viable alternatives are lacking (Interviews No. 21 \& 23, Sept. 2009).

The Enduimet WMA zoning system [64] restricts the numbers of livestock allowed to graze in the area and livestock entry into tourist investors' blocks. Such restrictions have caused local people to think they made a mistake in accepting the WMA concept, and men are querying the reason for imposing these restrictions (Interview No. 20, Sept. 2009). However, according to the data gathered from interviews, there were no reported cases of men being caught while grazing livestock illegally in the WMA.

\subsubsection{Impacts on Human-Wildlife Conflicts and Living costs}

The creation and expansion of PAs have created a conducive environment for wildlife to thrive. In both PAs in this study, wildlife movements have increased, thus exacerbating problems for local people as one woman expressed: "Wild animals destroy our crops so much. If you dare to say or complain they tell you, you are living in wildlife corridor. ...We are not allowed to kill them or beat them” (Interview No. 18, March 2010). The wildlife authorities do not allow people to kill crop raiding animals or depredating animals, as one woman lamented: “... They have stopped us from killing the wild animals when they eat our crops or kill our livestock, how does the CBO expect us to survive?” (Interview No. 21, Sept. 2009).

[77] study in the Kilimanjaro NP yielded similar findings namely that park rangers forbade local people to chase wildlife away from their farms because the animals would get high blood pressure. This attitude reflects a conservation bias in which biodiversity conservation is afforded higher priority than the needs of the local people.

Men and women share responsibility for guarding their farms during the night from crop raiding wildlife, although most of the responsibility lies with men. Women interviewed reported that crop raiding affects family wellbeing and it affects them more than men as one stated: “... at home when a child is hungry it cries to the mother for food, not to the father” (Interview No. 29, Sept. 2009). The effects of crop raiding differ from one 
family to another. This is because some families have farming plots in the forest plantation that are rarely affected by crop raiding animals, and some families have money to purchase food.

As wild animals move between the PAs, they not only raid crops, but also kill people and livestock. There have been several reports of people killed by wildlife mainly men and mostly by elephants in the evening or at night. For instance, from January through August 2009, in the Enduimet WMA, three men were attacked by elephants, and two by buffaloes. This reduces freedom of movement when men may need to stay outside later for various reasons such as guarding crops, and livestock grazing (Focus group, Nov. 2009).

The depredation of livestock in the area reduces the economic status of men. For instance, from January to August 2009, and from July to October 2010, 298 livestock were killed in the Enduimet WMA, and between March and August 2011, about 106 cattle in the village of Olmolog were killed by hyenas (ranking the highest), leopards, and lions. The increase in wildlife numbers has caused competition with livestock and people for water; this affects men because of grazing their livestock, and women fetching water for domestic use. Wildlife species like elephants have increased the workload of women because when they destroy water pipes women have to walk longer distances to fetch water.

In terms of increased living costs, the price of firewood has increased tremendously because the sellers (poor men and women) collect the firewood in harsh conditions (Interview No. 11, Nov. 2009). The lack of availability of these products has increased the time spent and labour required of individuals seeking such resources. Women in the village of Engare Nairobi claimed to use up to five hours per day searching for firewood and fodder which affects their back and chest (Interview No. 7, Dec. 2009). Similar findings have been reported in Nepal where women walk over $20 \mathrm{~km}$ per journey searching for firewood [29].

The Wildlife Act of 2009 provides for consolation payments in case of crop raiding, death, and depredation of livestock [78]. However, until 2014, no consolation amounts had been paid to local people in West Kilimanjaro, nor had any mechanisms or policies been put in place to mitigate negative impacts. Local people wonder why they are not being compensated for conservation costs as one woman questioned: "Do elephants have owners? Why we are not compensated when wild animals kill people and livestock, eat and destroy our crops? The problems remain to our children and us..." (Interview No. 28, Sept 2009). The government officials in the region and district offices claimed that the consolation payment process needs to pass through several levels of bureaucracy, which delays the outcome.

\subsubsection{Impacts on Relationship between Communities and Staff in Protected Areas}

The inability to access natural resources, harassments and punishments, and the lack of positive interaction between PA staff and communities, has led to hatred and enmity between them. Both men and women interviewed perceived PA staff as their enemies, as one man stated: “...Kilimanjaro NP work like military army... we see them as our enemies... there is nothing good coming from them. They are only increasing our problems...” (Interview No. 8, Aug. 2011).

The park rangers ignore village leadership and handle matters themselves when they catch someone in the forest. Female victims are harassed and males are taken directly to the district court after being beaten. The village government claimed that they obtain information on arrested individuals only later from the affected family (Interview No. 14, Aug. 2011). Although the park has promised to involve local people in park management [61] this is not happening in practice.

Due to enmity and resentment, men and women oppose conservation goals by increasing their illegal activities and sometimes even collaborating with poachers (Interview No. 14, Aug. 2011). For instance, in 2009, villagers in Engare Nairobi protested against conservation initiatives by killing six elephants by forcing them over a cliff [79]. In November 2014, Maasai pastoralists burnt 16 tourist tents to ashes, and 9 vehicles in the Endarakwai wildlife ranch due to conservation related costs (Interview No. 1 \& 2, Nov. 2014). Similar cases have been reported for example, in Indonesia [80], Guatemala [81], and Kenya [82].

In the Enduimet WMA, both men and women claimed to have been forced by the government and the African Wildlife Foundation to consent to the establishment of the WMA. They see the WMA as a form of exploitation. Both men and women expressed their hatred on game scouts as a result of the punishments they endure when they are caught in the WMA. They see the WMA as something that belongs completely to the government, as one man stated: "the government claimed to give us authority over WMA but what is happening is the government managing the WMA. We are complaining — we don't know where to go” (Focus group, Sept. 2009). 


\subsection{Who Is More Impacted by Protected Areas?}

As described above, both men and women suffer the consequences of restrictions on access to natural resources. However, women are more affected due to inequality in the division of labour and resources at the household level (cf. [28] [31]). Several interviews revealed that most men do not bother about issues pertaining to household energy requirements as much as women do: “...men do not think about challenges we encounter to get firewood... When they arrive home they just need cooked food, and they might be angry if you delay serving food" (Interview No. 52, Aug. 2011). Established traditions, especially in the Maasai community, do not allow men to assist women in activities such as collecting firewood, fetching water, or preparing meals.

Firewood collection is not only labour intensive, but it puts women at risk of violent acts, sexual assault, backache, exhaustion, falls and mental stress. Moreover, the activity is time consuming which restricts women's participation in education, development activities, decision-making activities, and having the opportunity to rest. In some instances, the burden placed on girls keeps them out of school, hampering their education, thus exacerbating gender inequalities. On the other hand, costs incurred by men such as fines, imprisonment, beatings or death, affect the welfare of the whole family. The family is also affected when there are delays in the provision of food, or meals are skipped as a result of time spent by the women searching or firewood.

The increase in wildlife numbers due to successful conservation measures means that wild animals tend to move outside the PAs. As a result, they kill people (mostly men), and livestock which affects the economic status of men. Wild animals also raid crops which affects both men and women in both cases. The destruction of water infrastructure affects both men and women but again, women suffer significantly since the collection of water for all domestic activities depends on them.

Well-off men and women suffer less compared to their poorer counterparts. They are capable of buying fodder and firewood, which is not an option for the poor. The poor men and women are forced to spend more time and labour in collecting natural resources which affects their health and restricts their time available for participation in economic activities or training/educational opportunities (cf. [30] [71]).

Households with farming plots in the forest plantation have access to firewood during pruning and harvesting periods. Also, families with bigger farms can plant trees and thus increasing their possibilities for access to firewood.

There are various differences between the conditions and restrictions in the two PAs. In the Enduimet WMA, about 26 Maasai men are employed in tourist camps, and 45 as game scouts. Some women sell handcrafts. In addition, women are allowed to collect firewood for household use. For the period of four years (2008 to 2011), each village received a share of tourism revenue for community development projects of about US\$9851. In the Kilimanjaro NP, the park has not employed any villager in the three selected villages. The park's outreach programme supported only the Matadi Secondary School in 2002/03 to construct a water intake and storage tank worth US\$13,571. However, natural resource access in the park for livelihood purposes is completely prohibited.

\subsection{Restrictions: Are There Alternatives?}

In the case of both PAs investigated in this study, resource extraction continues illegally, despite its many dangers, as one interviewee asserted: "is it possible for a poor person to live next to the forest without a buffer zone and watch the forest without resource extraction? ... Obviously resource extraction will occur illegally ... (Interview No. 9, 2011). Another stated without hesitation: "We still collect firewood, fodder and traditional medicine from the forest clandestinely ... because there is no other solution" (Interview No. 19, Dec. 2009). The charcoal burning continues to be conducted illegally in the Enduimet WMA. For instance, from 2012 to 2014, 112 sacks and 12 charcoal kilns were destroyed by the WMA game scouts. "Illegal hunting" is still practised in some villages, mostly by non-Maasai men, as a source of finance and protein (Interview No. 50, Nov. 2009).

Firewood is provided freely by the Kilimanjaro Forest Plantation during the pruning and harvesting season, but it benefits only those people with plots in the forest plantation, and then only during the short periods when pruning or harvesting is conducted. Some people who have an income manage to buy fodder and firewood. Others supplement firewood with maize husks, sawdust and kerosene for the provision of household energy.

Lack of subsistence alternatives, has led many families to continue practising farming regardless of crop raiding animals that pose a significant constraint to farming attempts. In order to protect crops, people still guard their crops at night and sometimes kill problem animals (Interview No. 20, Nov. 2009). Furthermore, the in- 
crease in costs as a result of conservation, and lack of livelihood and subsistence alternatives, has sometimes led local people to resist conservation initiatives, using overt or covert methods (See [79]).

\section{Conclusions}

Gender relations frame the ownership of assets and access to resources, and affect structure and decision making within families, communities, and institutions [53] [54]. This means that conservation interventions are likely to create different impacts on men and women and lead to deliver varying costs and benefits for both basing on this relationship. In accordance with the WED school of thought as well as feminist political ecology, the findings show how changes in resource access and control as a result of land appropriation by powerful actors (the State and conservation agencies), have impacted men and women in rural Tanzania. The approach has been useful in illuminating the injustices and struggles of both men and women in the process of trying to sustain their everyday life in the midst of changes in resource access and control [24]. Further, it has shed light on how access to and the control of resources are affected by the social construction of gender, as well as power relations and authority that are embedded in formal and informal institutions (cf. [70]). The discussion of the micro-politics of everyday natural resources access and control has offered a hint of understanding into the broader macro-political forces at work in natural resources conservation. This investigation of everyday gender experiences of conservation in west Kilimanjaro shows the mismatch between the rhetoric and practice of conservation and the challenges in combining conservation and development agendas.

The main impacts identified in this study include those associated with natural resource restrictions, illegal entry into PAs, human-wildlife conflicts, increases in living costs, and poor relationships between PA staff, and men and women. These findings dovetail with the growing body of literature on the gendered impacts of conservation initiatives (e.g. [20] [28] [31]).

There are variations between the two PAs studied. In the Enduimet WMA, men and women have access to natural resources for household use, and derive some direct and indirect benefits from tourism activities, while in the Kilimanjaro NP, resource access is denied and local tourism benefits are minimal. The PAs impact both men and women, but the most significant impact is felt by women due to inequality in the gendered division of labour and resources at the household level. Further, poor men and women are stricken more severely since they lack livelihood and subsistence alternatives. In addition, women in female-headed households are affected more than their counterparts in male-headed households.

This study found that the PAs' attempt at benefit sharing as compensation for resource restrictions does not meet the felt needs of men and women. The PAs function in such a way that they have aggravated people's workloads and risks, instead of addressing community interests, paying attention to relevant livelihood needs, or improving wellbeing.

\section{Acknowledgements}

I humbly acknowledge the projects EKOSIASA (Political Ecology of Wildlife and Forest Governance in Tanzania) and PAPIA (Protected Areas and Poverty in Africa) for financial support. Also, I acknowledge Professors T. A. Benjaminsen, Hanne Svarstad and Ingrid Nyborg who gave valuable comments.

\section{References}

[1] Roe, D. and Elliott, J. (2006) Pro-Poor Conservation: The Elusive Win-Win for Conservation and Poverty Reduction? Policy Matters, 14, 53-63.

[2] Timko, J.A., Waeber, P.O. and Kozak, R.A. (2010) The Socio-Economic Contribution of Non-Timber Forest Products to Rural Livelihoods in Sub-Saharan Africa: Knowledge Gaps and New Directions. International Forestry Review, 12, 284-294. http://dx.doi.org/10.1505/ifor.12.3.284

[3] Kikoti, A. (2009) Seasonal Home Range Sizes, Transboundary Movements and Conservation of Elephants in Northern Tanzania. Ph.D. Thesis, University of Massachusetts, USA.

[4] Brooks, T.M., Wright, S.J. and Sheil, D. (2009) Evaluating the Success of Conservation Actions in Safeguarding Tropical Forest Biodiversity. Conservation Biology, 23, 1448-1457. http://dx.doi.org/10.1111/j.1523-1739.2009.01334.x

[5] Veit, P.G. and Benson, C. (2004) When Parks and People Collide. Environmental Rights, Spring, 13-14.

[6] UN MGD (2010) The Millennium Development Goals Report. United Nations, New York. 
[7] Naughton-Treves, L., Holland, M.B. and Brandon, K. (2005) The Role of Protected Areas in Conserving Biodiversity and Sustaining Local Livelihoods. Annual Review of Environment and Resources, 30, 219-252. http://dx.doi.org/10.1146/annurev.energy.30.050504.164507

[8] Scherl, L.M., Wilson, A., Wild, R., Blockhus, J., Franks, P., McNeely, J.A. and McShane, T.O. (2004) Can Protected Areas Contribute to Poverty Reduction? Opportunities and Limitations. CSO Report, International Union for Conservation of Nature, Gland. http://dx.doi.org/10.2305/IUCN.CH.2005.6.en

[9] Nelson, F. (2004) Conservation and Poverty Reduction. Miombo, No. 27, July 2004, Dar es Salaam.

[10] Johnsen, F.H. (1999) Burning with Enthusiasm: Fuel Wood Scarcity in Tanzania in Terms of Severity, Impacts and Remedies. Forum for Development Studies, 1, 107-132. http://dx.doi.org/10.1080/08039410.1999.9666097

[11] United Republic of Tanzania (URT) (1998) The National Forest Policy of Tanzania. Ministry of Natural Resources and Tourism, Dar es Salaam.

[12] Benjaminsen, T.A. and Svarstad, H. (2010) The Death of an Elephant: Conservation Discourses versus Practices in Africa. Forum for Development Studies, 37, 385-408. http://dx.doi.org/10.1080/08039410.2010.516406

[13] Balmford, A., Bruner, A., Cooper, P., Costanza, R., Farber, S., Green, R.E., et al. (2002) Economic Reasons for Conserving Wild Nature. Science, 297, 950-953. http://dx.doi.org/10.1126/science.1073947

[14] TEEB (2010) Ecological and Economic Foundation. The Economics of Ecosystems and Biodiversity, Earthscan Books, UK.

[15] Adams, W.M. and Hutton, J. (2007) People, Parks and Poverty: Political Ecology and Biodiversity Conservation. Conservation and Society, 5, 147-183.

[16] Cernea, M. and Schmidt-Soltau, K. (2006) Poverty Risks and National Parks: Policy Issues in Conservation and Resettlement. World Development, 34, 1808-1830. http://dx.doi.org/10.1016/j.worlddev.2006.02.008

[17] West, P., Igoe, J. and Brockington, D. (2006) Parks and Peoples: The Social Impact of Protected Areas. Annual Review of Anthropology, 35, 251-277. http://dx.doi.org/10.1146/annurev.anthro.35.081705.123308

[18] Borrini-Feyerabend, G., Pimbert, M., Farvar, M.T., Kothari, A. and Renard, Y. (2004) Sharing Power: Learning by Doing in Co-Management of Natural Resources throughout the World. IIED and IUCN/CEESD, Tehran.

[19] Colchester, M. (2002) Wilderness Parks or Community Conservation? World's Bulletin No. 62, Uruguay.

[20] Coad, L., Campbell, A., Miles, L. and Humphries, K. (2008) The Costs and Benefits of Protected Areas for Local Livelihoods: A Review of the Current Literature. Working Paper, UNEP, Cambridge.

[21] Vedeld, P., Anglesen, A., Bojo, J., Sjaaastad, E. and Berg, G.K. (2007) Forest Environmental Incomes and the Rural Poor. Forest Policy and Economics, 9, 869-879. http://dx.doi.org/10.1016/j.forpol.2006.05.008

[22] Clements, T., Suon, S., Wilkie, D.S. and Milner-Gulland, E.J. (2014) Impacts of Protected Areas on Local Livelihoods in Cambodia. World Development, 64, S125-S134. http://dx.doi.org/10.1016/j.worlddev.2014.03.008

[23] Agrawal, A. and Gibson, C.C. (2001) The Role of Community in Natural Resource Conservation. In: Agrawal, A. and Gibson, C.C., Eds., Communities and the Environment: Ethnicity, Gender, and the State in Community-Based Conservation, Rutgers University Press, New Brunswick, 1-31.

[24] Rocheleau, D., Thomas-Slayter, B. and Wangari, E. (1996) Feminist Political Ecology: Global Issues and Local Experiences. Routledge, London.

[25] Asimalowo, A. and Lipsanen, H. (1998) Gender Participation in Natural Resource Management in the East Usambara Mountains. FAO, Accra.

[26] Practical Action (2012) Poor People’s Energy Outlook 2012: Energy for Earning a Living. Practical Action Publishing, Rugby.

[27] Barua, M., Bhagwat, S.A. and Jadhav, S. (2012) The Hidden Dimensions of Human-Wildlife Conflict: Health Impacts, Opportunity and Transaction Costs. Biological Conservation, 157, 309-316. http://dx.doi.org/10.1016/j.biocon.2012.07.014

[28] Ogra, M. (2008) Human-Wildlife Conflict and Gender in Protected Area Borderlands: A Case Study of Costs, Perceptions, and Vulnerabilities from Uttarakhand (Uttaranchal), India. Geoforum, 39, 1408-1422. http://dx.doi.org/10.1016/j.geoforum.2007.12.004

[29] Mahat, I. (2006) Gender and Rural Energy Technologies: Empowerment Perspectives: A Case Study of Nepal. Canadian Journal of Development Studies, 27, 531-550.

[30] Clancy, J., Skutsch, M. and Batchelor, S. (2003) The Gender-Energy-Poverty Nexus: Finding the Energy to Address Gender Concerns in Development. Department for International Development (DFID), London.

[31] Sarin, M., Lipka, R., Raju, M.S., Chatterjee, M., Banerjeeand, N. and Hiremath, S. (1998) Who Is Gaining? Who Is Losing? Gender and Equity Concerns in Joint Forest Management. Working Paper, Society for the Promotion of 
Wastelands Development (SPWD), New Delhi.

[32] Songorwa, A.N. (1999) Is Community Based Wildlife Management Gender Sensitive? Experiences from Selous Conservation Programme in Tanzania. Uongozi Journal, 11, 145-166.

[33] Makalle, A.M. (2012) Gender Relations in Environmental Entitlements: Case of Coastal Natural Resources in Tanzania. Environment and Natural Resources Research, 2, 128-142. http://dx.doi.org/10.5539/enrr.v2n4p128

[34] Mhache, E.P. (2014) Gender Division and Utilization of Natural Resources: A Case Study of Mindu-Tulieni and Makombe Villages in Bagamoyo District, Tanzania. Journal of the Open University of Tanzania, 16, 25-48.

[35] Kaarhus, R., Benjaminsen, T.A., Hellum, A. and Ikdahl, I. (2005) Women’s Land Rights in Tanzania and South Africa: A Human Rights Based Perspective on Formalisation. Forum for Development Studies, 32, 443-482. http://dx.doi.org/10.1080/08039410.2005.9666323

[36] Mariki, S.B. (2013) Conservation with a Human Face? Comparing Local Participation and Benefit Sharing from a National Park and a State Forest Plantation in Tanzania. Sage Open, 3, 1-16. http://dx.doi.org/10.1177/2158244013512665

[37] United Republic of Tanzania (URT) (1998) The Wildlife Policy of Tanzania. Ministry of Natural Resources and Tourism, Dar es Salaam.

[38] Cornwall, A. (2003) Whose Voices? Whose Choices? Reflections on Gender and Participatory Development. World Development, 31, 1325-1342. http://dx.doi.org/10.1016/s0305-750x(03)00086-x

[39] Braidotti, R., Charkiewics, E., Haüsler, S. and Wierenga, S. (1994) Women the Environment and Sustainable Development: Towards a Theoretical Synthesis. Zed Books, London.

[40] Agarwal, B. (1997) Environmental Action, Gender Equity and Women’s Participation. Development and Change, 28, 1-44. http://dx.doi.org/10.1111/1467-7660.00033

[41] Joekes, S., Heyzer, N., Oniang'o, R. and Salles, V. (1994) Gender, Environment and Population. Development and Change, 25, 137-165. http://dx.doi.org/10.1111/j.1467-7660.1994.tb00512.x

[42] Ceceski, E. (2000) Enabling Equitable Access to Rural Electrification: Current Thinking and Major Activities in Energy Poverty and Gender. Briefing Paper, Asia Alternative Energy Unit, World Bank, 26-27 January 2000.

[43] Green, C., Joekes, S. and Leach, M. (1998) Questionable Links: Approaches to Gender in Environmental Research and Policy. In: Jackson, C. and Pearson, R., Eds., Feminist Visions of Development: Gender Analysis and Policy, Routledge, London and New York, 259-283.

[44] Sachs, C. (1997) Women Working in the Environment. Taylor and Francis, Washington DC.

[45] Martin, P.Y. (2004) Gender as Social Institution. Social Forces, 82, 1249-1273. http://dx.doi.org/10.1353/sof.2004.0081

[46] Locke, C. (1999) Constructing a Gender Policy for Joint Forest Management in India. Development and Change, 30, 265-285. http://dx.doi.org/10.1111/1467-7660.00117

[47] Jackson, C. and Palmer-Jones, R. (1999) Rethinking Gendered Poverty and Work. Development and Change, 30, 145-156. http://dx.doi.org/10.1111/1467-7660.00129

[48] Elmhirst, R. (2011) Introducing New Feminist Political Ecologies. Geoforum, 42, 129-132. http://dx.doi.org/10.1016/j.geoforum.2011.01.006

[49] Nightingale, A. (2006) The Nature of Gender: Work, Gender and Environment. Environment and Planning D: Society and Space, 24, 165-185. http://dx.doi.org/10.1068/d01k

[50] Rocheleau, D.E. (2008) Political Ecology in the Key of Policy: From Chains of Explanation to Webs of Relation. Geoforum, 39, 716-727. http://dx.doi.org/10.1016/j.geoforum.2007.02.005

[51] Ahmed, S. (2001) Empowering Rural Women? Policies, Institutions, and Gendered Outcomes in Natural Resources Management. Development in Practice, 11, 535-537. http://dx.doi.org/10.1080/09614520120066800

[52] Peet, R. and Watts, M. (1996) Liberation Ecologies: Environment, Development, Social Movements. Routledge, London. http://dx.doi.org/10.4324/9780203286784

[53] Anoko, J.N. (2008) Gender and Equity in the Protected Areas of West Africa. http://www.lafiba.org/var/plain/storage/original/application/0d396aabbb9ce4b97f43a306803c0add.pdf

[54] Espinosa, M.C. (2010) Why Gender in Wildlife Conservation? Notes from the Peruvian Amazon. The Open Journal of Anthropology, 3, 230-241. http://dx.doi.org/10.2174/1874912701003010230

[55] Agarwal, B. (1998) Who Sows? Who Reaps? Women and Land Rights in India. The Journal of Peasant Studies, 15, 532-581.

[56] Kivumbi, C.O. and Newmark, W.D. (1991) The History of the Half-Mile Forestry Strip on Mount Kilimanjaro. In: Newmark, W.D., Ed., The Conservation of Mount Kilimanjaro, IUCN, Gland, 81-86. 
[57] TASONABI (2001) Forest Landscape Restoration Tanzania Country Report. International Union for Conservation of Nature and WWF, Gland.

[58] Lambrechts, C., Woodley, B., Hemp, A., Hemp, C. and Nnyiti, P. (2002) Aerial Survey of the Threats to Mt. Kilimanjaro Forests. Report, UNDP, Dar es Salaam.

[59] Agrawal, S., Moehner, A., Hemp, A., van Aalst, M., Hitz, S., Smith, J., Meena, H., Mwakifwamba, S.M., Hyera, T. and Mwaipopo, O.U. (2003) Development and Climate Change in Tanzania: Focus on Mount Kilimanjaro. Organisation for Economic Co-Operation and Development (OECD) Papers, Vol. 4, No. 1, OECD, Paris, 72 p.

[60] UNESCO (2011) Kilimanjaro National Park. Brief Description. http://whc.unesco.org/en/list/403

[61] GMP (2006) Kilimanjaro National Park. General Management Plan 2006-2015. Tanzania National Parks Authority, Arusha.

[62] Mongo, C.L. (2007) Socio-Economic Analysis of Production Options of the Buffer Zone around Mount Kilimanjaro Catchment Forest Reserve. MSc Dissertation, Sokoine University of Agriculture, Morogoro.

[63] Nelson, F. (2007) Emergent or Illusory? Community Wildlife Management in Tanzania. International Institute for Environment and Development (IIED), London, $31 \mathrm{p}$.

[64] RMZP (2005) Enduimet Wildlife Management Area Resource Management Zone Plan. Monduli District Council, Monduli.

[65] Ngoitiko, M. (2008) The Pastoral Women’s Council: Empowerment for Tanzania’s Maasai. IIED Gatekeeper 137e, International Institute for Environment and Development (IIED), London.

[66] Kipuri, N. and Ridgewell, A. (2008) A Double Bind: The Exclusion of Pastoralist Women in the East and Horn of Africa. Report. Minority Rights Group International, London.

[67] Hodgson, D.L. (2001) Once Intrepid Warriors: Gender, Ethnicity, and the Cultural Politics of Maasai Development. Indiana University Press, Bloomington.

[68] National Bureau of Statistics (NBST) (2002) Household Budget Survey 2000/01. NBST, Dar es Salaam, 188 p.

[69] Neumann, R.P. (2004) Moral and Discursive Geographies in the War for Biodiversity in Africa. Political Geography, 23, 813-837. http://dx.doi.org/10.1016/j.polgeo.2004.05.011

[70] Rantala, S.E., Vihemäki, H., Swallow, B.M. and Jambiya, G. (2013) Who Gains and Who Loses from Compensated Displacement from Protected Areas? The case of the Derema Corridor, Tanzania. Conservation and Society, 11, 97-111. http://dx.doi.org/10.4103/0972-4923.115721

[71] Cecelski, E. (1995) From Rio to Beijing: Engendering the Energy Debate. Energy Policy, 23, 561-575. http://dx.doi.org/10.1016/0301-4215(95)91241-4

[72] Monela, G.C. (1989) A Socio-Economic Analysis of Forest Plantation: A Case of Meru Forest Project, Arusha, Tanzania. MSc Thesis, Sokoine University of Agriculture, Morogoro.

[73] Pettersen, E.D. (2010) Livelihoods and Conflicts around Kilimanjaro National Park, Tanzania. MSc Dissertation, Norwegian University of Life Sciences, Ås.

[74] Benjaminsen, T.A. and Bryceson, I. (2012) Conservation, Green/Blue Grabbing and Accumulation by Dispossession in Tanzania. Journal of Peasant Studies, 39, 335-355. http://dx.doi.org/10.1080/03066150.2012.667405

[75] Brockington, D. and Igoe, J. (2006) Eviction for Conservation: A Global Overview. Conservation and Society, 4, 424-470.

[76] Amanor, K., Osei, E. and Gyampoh, K. (Eds.) (2005) Proceedings of a Workshop on Charcoal Burning in the Kintampo Districts: Policies, Environment and Livelihoods Issues, Kintampo North District, 29 June 2005. Institute of African Studies, University of Ghana, Legon, 28 p.

[77] Lerkelund, H. (2011) A Local Narrative of Exclusion: The Case of Kilimanjaro National Park. MPhil, University of Oslo, Oslo.

[78] United Republic of Tanzania (URT) (2009) The Wildlife Conservation Act. Ministry of Natural Resources and Tourism, Dar es Salaam.

[79] Mariki, S.B., Svarstad, H. and Benjaminsen, T.A. (2015) Elephants over the Cliff: Explaining Wildlife Killings in Tanzania. Land Use Policy, 44, 19-30. http://dx.doi.org/10.1016/j.landusepol.2014.10.018

[80] Li, T.M. (2007) The Will to Improve: Governmentality, Development, and the Practice of Politics. Duke University Press, Durham. http://dx.doi.org/10.1215/9780822389781

[81] Meyerson, F. (1998) Guatemala Burning. Amicus Journal, 20, 28-32.

[82] Western, D., Wright, R.M. and Strum, S.C. (Eds.) (1994) Natural Connections: Perspectives in Community-Based Conservation. Island Press, Washington DC. 